\title{
Chromosomal Analysis in Cultured Cells of Barley (Hordeum vulgare L.): Structural Alterations in Chromosomes
}

\author{
B. D. Mohanty', P. D. Ghosh and S. Maity ${ }^{2}$ \\ Depatment of Botany, University of Kalyani, West Bengal 741 235, India
}

Accepted October 26, 1990

Chromosomal instability of callus and cell suspension cultures have often been reported (D'Amato 1977). Chromosomal instability in cells grown in vitro not only includes numerical variations, but also comprises changes in chromosome structrure and basic karyotype (Sunderland 1977). Numerical changes have been examined most often (Evans and Reed 1981). A detailed assessment of chromosome rearrangement or other structural changes requires sophisticated karyotype analysis or chromosomal banding technique (Evans and Reed 1981). Unfortunately detailed analysis of chromosomal rearrangement has been completed only in Crepis capillaris (Scristan 1971). Despite of several attempts, we were not able to standardize a reproducible banding technique for barley chromosomes. Regenerability of a callus is often ascribed to numerical and structural changes in the chromosomes (Muir 1965, Murashige and Nakano 1965, Torrey 1967). Chromosomal interchanges have been described to be a basis for obtaining somaclonal variation (Pijnaker and Ferweda 1987, Krap and Bright 1985). In barely, variability in callus cultrue has been observed to be expressed within the regenerants (Orton 1980). Recently we have reported the chromosome number variation in cultured cells of barley (Mohanty 1990). In the present communication we report the structural aberrations of the chromosomes of different ploidy levels obtained from cultured cell karyotypes of barley.

\section{Materials and methods}

The root tips obtained from germinating barley seeds (served as control) and 150 days old mesocotyl-explant derived calluses of barley (Mohanty 1987, Mohanty 1990) were pretreated with $\alpha$-bromonaphthalene for $3 \mathrm{hr}$, washed several times with distilled water and fixed with aceto-ethanol $(1: 3)$ for $8 \mathrm{hr}$. The fixed materials were then hydrolysed in $1 \mathrm{~N} \mathrm{HCl}$ for $8 \mathrm{~min}$ at $58^{\circ} \mathrm{C}$ and stained with aceto-orcein. Randomly selected small portions of the stained callus were squashed and mounted in $45 \%$ acetic acid. For karyotype analysis, 14 well spread metaphase cells were randomly selected from temporary slide preparations. The karyotypes containing folded or twisted form of chromosomes were not taken into consideration. Idiograms and subsequent analyses were performed from the camera lucida drawings of individual karyotypes drawn at a magnification of $1500 \mathrm{X}$. Karyomorphology of metaphase chromosomes in cultured cells were analysed considering the following parameters: (i) absolute length of the individual chromosomes in micron (s), (ii) arm index ( $\mathrm{r}$ ) and form percent $(\mathrm{F} \%$ ) value for determining the nature of primary construction in the chromosomes (Krikorian et al. 1983), (iii) relative length of the chromosome complement (Krikorian et al. 1983), and (iv) disparity index (DI) of chromosomes in a karyotype was calculated as follows:

${ }^{1}$ For correspondence and reprints.

${ }_{2}$ Department of Genetics and Plant Breeding, Bidhan Chandra Krishi Viswavidyalaya, Kalyani-741 235 , India. 


$$
\mathrm{DI}=\frac{\text { Longest chromosome }- \text { Shortest chromosome }}{\text { Longest chromosome }+ \text { Shortest chromosome }} \times 100
$$

\section{Results and discussion}

Structurally altered chromosomes were readily observead in the karyotypes of the cultured cells in the form of dicentric and acrocentric chromosomes. Occurrence of chromosomal

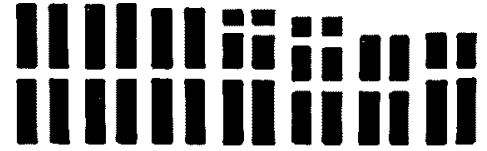

A

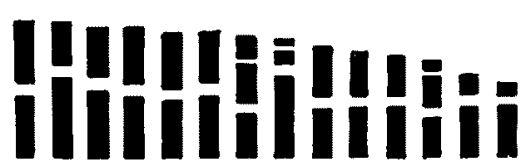

C

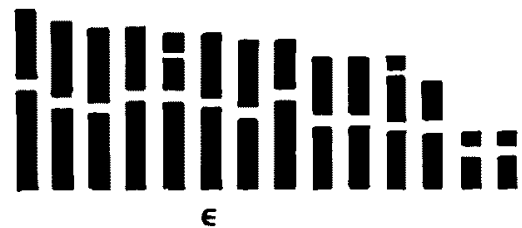

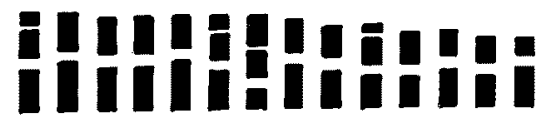

$\mathbf{B}$

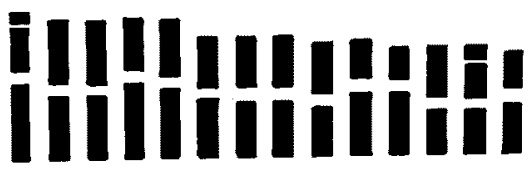

D

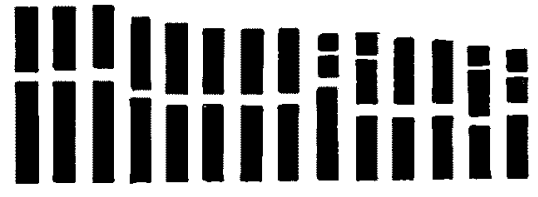

$\boldsymbol{F}$

Fig. 1. A-F.

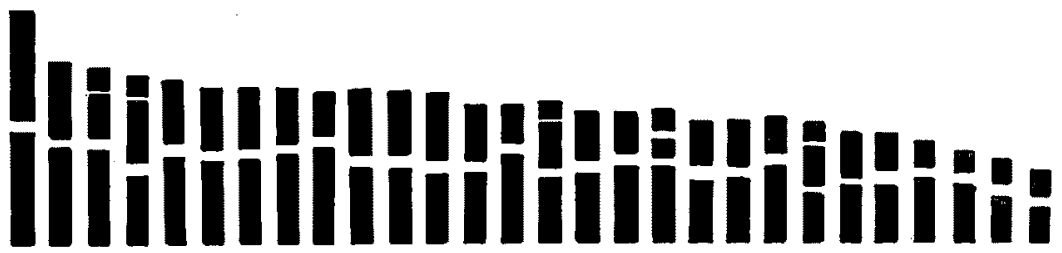

$\mathbf{G}$

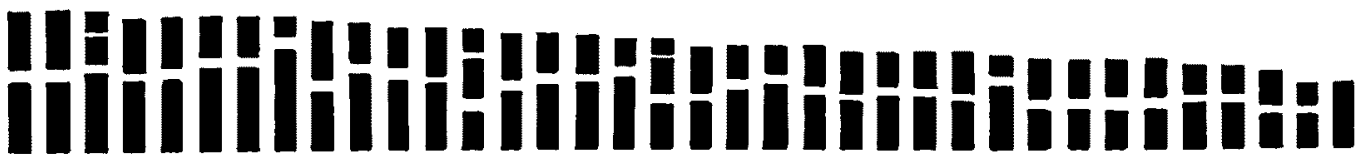

H

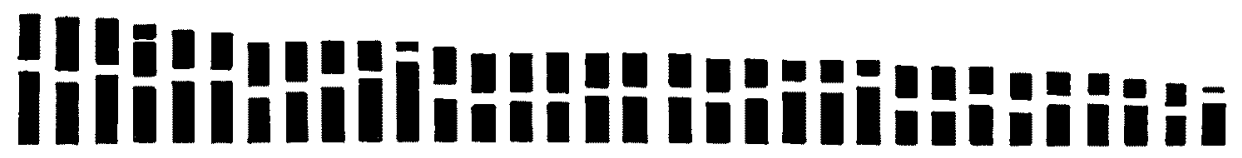

Fig. 1. G-I. 


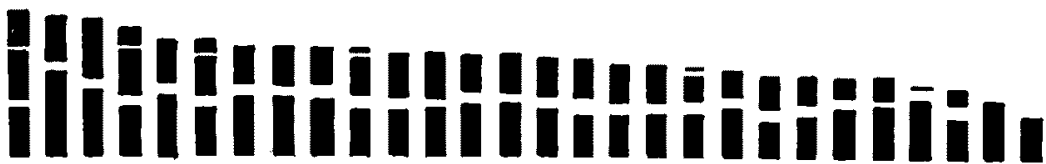

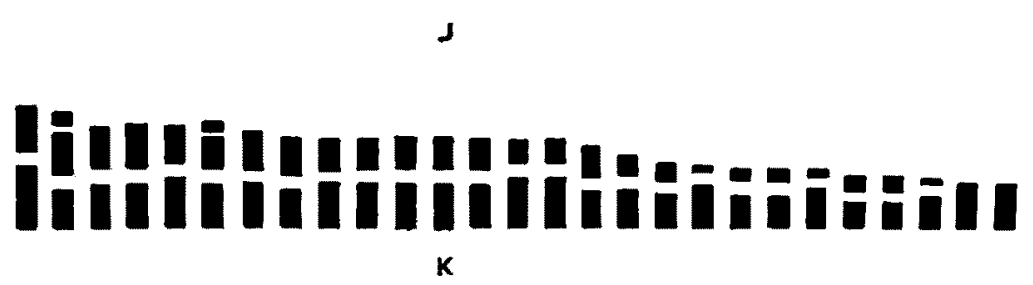

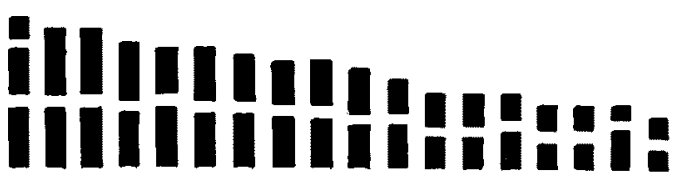

L

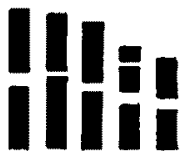

$\mathbf{N}$

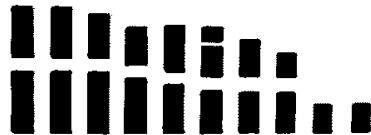

$\mathbf{M}$

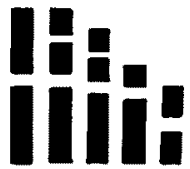

$\mathbf{0}$

Fig. 1. J-O.

Fig. 1. A-O, Idiograms of callus cells chromosomes of Hordeum vulgare L. A, Idiogram of a normal diploid root tip cell $(2 n=14)$. B-F, Idiograms of diploid callus cells karyotypes $(2 n=14)$ showing changes in basic karyotype nature due to structural alteration in chromosomes. $\mathrm{G}$, an aberrant tetraploid callus cell $(2 n=28)$. H-N, Idiograms of aneuploid callus cell with aberrant chromosomes $(2 n=36,2 n=32,2 n=26,2 n=25,2 n=18$ and $2 n=8)$. N and $O$ callus cells idiograms showing $2 n=5$ chromosomes each, but their karyotypes varied due to different degrees of structural aberration in chromosomes.

fragements in cultured metaphase cells also indicated structural altearations in chromosomes througth deletion. In order to quantify all the minor and major structural changes, randomly selected 14 well spread metaphase plates selected from 5 callus samples were drawn. Idiograms were constructed (Fig. $1 \mathrm{~A}-\mathrm{O}$ ). The chromosomes were classified into eight groups and there were four types in each group. The eight groups were A, B, C, D, AS, BS, CS and DS. The four types were $A_{1}, A_{2}, A_{3}, A_{4}$ for $A$ group, $B_{1}, B_{2}, B_{3}$ and $B_{4}$ for $B$ group and so on. Comparative analysis of the founrteen cultured karyotypes is depicted in Table 1. Analysis of these cultured karyotypes was performed with reference to a control karyotype, obtained from the root tip squashes of the same cultivar. All the 14 cultured karyotypes with control classified to different groups and types described supra, are presented in Table 1. It is evident that number of satellite chromosomes in cultured metaphase cells varied from minimum 1 to maximum 5. For most of the cultured karyotypes, disparity index (DI) was higher compared to control karyotype (Table 1). Structurally altered chromosomes were frequently encountered under the cultural conditions irrespective of the ploidy status of the karyotypes (Tables 1 and 2). These altered chromosomes formed different types or groups deapending upon the degree of aberration (s). The average frequency $(\%)$ of normal and structurally altered chromosomes in diploid, tetraploid and aneuploid callus cells is presented in Table 2. Analysis of diploid karyotypes revealed both major and minor structural changes in the chromosomes. 
Although, the callus cells showed same ploidy level $(2 n=14)$ as in the original plant (Fig. 1 A-F), the basic karyotype nature was changed due to structural rearrangement in chromosomes. An average of $44 \%$ structurally altered chromosomes were analysed from the cultured diploid karyotypes (Table 2). The frequency of aberrations within the chromosome groups of a specific karyotype also varied. In control root tip squashes $(2 n=14)$ the satellite group of chromosomes (BS) were contributed to $28.5 \%$ of the total chromosomes. However, in diploid callus cells $(2 \mathrm{n}=14)$ only $7.1 \%$ satellite chromosomes were strucaturally similar to control, $4.2 \%$ satellite chromosomes were found with minor structural changes and rest were eliminated from the cells (Tables 2 and 3). These mninor structural changes placed them in different new types within the sateilite group (Table 2). Interestingly a new typical non-

Table 1. Comparative accounts of 14 cultured karyotypes of mesocotyl callus cells of Hordeum vulgare

\begin{tabular}{|c|c|c|c|c|}
\hline $\begin{array}{c}\text { Karyo } \\
\text { type }\end{array}$ & $\begin{array}{l}\text { Chromosome } \\
\text { number } \\
(2 n)\end{array}$ & $\begin{array}{c}\text { No. of } \\
\text { satellite } \\
\text { chromosomes }\end{array}$ & $\mathrm{DI} \%$ & Karyotype formulae \\
\hline $\begin{array}{c}\text { Control } \\
\text { (root tip) }\end{array}$ & 14 & 4 & 14.28 & $6 \mathrm{~B}_{1}+2 \mathrm{C}_{1}+2 \mathrm{C}_{2}+4 \mathrm{BS}_{1}$ \\
\hline \multicolumn{5}{|l|}{$\begin{array}{l}\text { Culture } \\
\text { karyotype } \\
\text { (No.) }\end{array}$} \\
\hline 1 & 14 & 4 & 21.73 & $5 C_{1}+1 C_{2}+3 D_{1}+1 D_{2}+2 C_{1}+1 C_{2}+1 D_{1}$ \\
\hline 2 & 14 & 3 & 33.33 & $6 \mathrm{~B}_{1}+1 \mathrm{~B}_{2}+2 \mathrm{C}_{2}+1 \mathrm{C}_{3}+1 \mathrm{D}_{3}+1 \mathrm{BS}_{2}+1 \mathrm{BS}_{4}+1 \mathrm{DS}$ \\
\hline 3 & 14 & 2 & 17.64 & $8 \mathrm{~B}_{1}+1 \mathrm{~B}_{2}+1 \mathrm{C}_{1}+1 \mathrm{C}_{2}+1 \mathrm{BS}_{2}+2 \mathrm{CS}_{2}$ \\
\hline 4 & 14 & 4 & 58.82 & $5 A_{1}+3 B_{1}+1 B_{2}+1 C_{1}+2 D_{3}+1 A_{2}+1 B_{1}$ \\
\hline 5 & 14 & 4 & 20.93 & $2 \mathrm{~A}_{1}+3 \mathrm{~A}_{2}+5 \mathrm{~B}_{1}+3 \mathrm{BS}_{1}+1 \mathrm{BS}_{2}$ \\
\hline 6 & 28 & 5 & 60.00 & $\begin{array}{l}5 \mathrm{~A}_{1}+2 \mathrm{~A}_{2}+8 \mathrm{~B}_{1}+2 \mathrm{C}_{2}+2 \mathrm{C}_{1}+2 \mathrm{C}_{3}+1 \mathrm{D}_{1}+1 \mathrm{D}_{2} \\
+2 \mathrm{AS}_{1}+1 \mathrm{BS}_{1}+2 \mathrm{BS}_{2}\end{array}$ \\
\hline 7 & 36 & 2 & 42.86 & $\begin{array}{l}7 \mathrm{~B}_{1}+5 \mathrm{~B}_{2}+1 \mathrm{~B}_{4}+8 \mathrm{C}_{1}+7 \mathrm{C}_{2}+2 \mathrm{C}_{3}+1 \mathrm{D}_{1}+1 \mathrm{D}_{2} \\
+2 \mathrm{BS}_{2}+1 \mathrm{BS}_{3}+1 \mathrm{CS}_{4}+1 \mathrm{~F}\end{array}$ \\
\hline 8 & 32 & 1 & 46.15 & $\begin{array}{l}1 \mathrm{~B}_{1}+3 \mathrm{~B}_{2}+10 \mathrm{C}_{1}+3 \mathrm{C}_{2}+3 \mathrm{C}_{3}+2 \mathrm{C}_{4}+5 \mathrm{D}_{1}+2 \mathrm{D}_{2} \\
+1 \mathrm{D}_{3}+1 \mathrm{D}_{4}+1 \mathrm{BS}_{1}\end{array}$ \\
\hline 9 & 26 & 5 & 31.03 & $\begin{array}{l}1 \mathrm{~A}_{2}+9 \mathrm{~B}_{1}+6 \mathrm{C}_{1}+2 \mathrm{C}_{2}+1 \mathrm{C}_{3}+1 \mathrm{C}_{4}+1 \mathrm{D}_{2}+1 \mathrm{AS}_{2} \\
+3 \mathrm{BS}_{1}+1 \mathrm{BS}_{4}+2 \mathrm{~F}\end{array}$ \\
\hline 10 & 25 & 2 & 47.83 & $1 \mathrm{~B}_{1}+11 \mathrm{~B}_{4}+2 \mathrm{C}_{1}+4 \mathrm{D}_{2}+2 \mathrm{D}_{3}+3 \mathrm{D}_{4}+2 \mathrm{DS}_{1}+2 \mathrm{~F}$ \\
\hline 11 & 18 & 1 & 53.80 & $6 \mathrm{~B}_{1}+4 \mathrm{C}_{1}+6 \mathrm{D}_{1}+1 \mathrm{D}_{3}+1 \mathrm{BS}_{1}$ \\
\hline 12 & 8 & 1 & 24.13 & $3 B_{1}+3 C_{1}+1 C_{2}+1 C_{1}+2 F$ \\
\hline 13 & 5 & 1 & 25.00 & $3 \mathrm{~B}_{1}+1 \mathrm{C}_{1}+1 \mathrm{CS}_{1}$ \\
\hline 14 & 5 & 2 & 37.05 & $1 \mathrm{~B}_{1}+1 \mathrm{C}_{3}+1 \mathrm{D}_{1}+1 \mathrm{BS}_{1}+1 \mathrm{BS}_{2}$ \\
\hline
\end{tabular}

$\mathrm{A}=$ Very long chromosomes $(15-24 \mu \mathrm{m})$ without satellite; $B=$ long chromosomes $(10-14.99 \mu \mathrm{m})$ without satellite; $\mathrm{C}=$ Medium sized chromosomes $(7-9.9 \mu \mathrm{m})$ without satellite; $\mathrm{D}=$ Short sized chromosomes (3-6.99 $\mu \mathrm{m})$ with satellite; $\mathrm{AS}=$ chromosomes very long $(15-24 \mu \mathrm{m})$ with satelite; $\mathrm{BS}=$ chromosomes long (10-14.99 $\mu \mathrm{m})$ with satellite. Script $1=$ form percent, $40-50,2=$ form percent, $30-39.99 ; 3=$ form percent $20-20.99,4=$ form percent 10-19.99, $\mathrm{F}=$ acentric chromosomal fragment.

satellite group having very long, metacentric to nearly metacentric chromosomes (A), appeared considerable frequency $(10 \%)$ in the cultured diploid karyotypes (Table 2). Origin of this group of chromosomes might be due to non-reciprocal tranlocation. It has been observed than plant regeneration in callus culture mostly selects cells with diploid chromosome number (Vasil 1983, Larkin and Scowcroft 1981). Variation within the regenerated plants (Somaclonal variation) is often reported (Larkin and Scowcroft 1981, Scoweroft 1984, McCoy and Phillips 1982). The possibility of minor genetic reshuffles in the form of minor structural changes in chromosomes, without affecting their original chromosome number as the origin of variants in regenerants can not be ruled out. Thus, the callus culture can be proposed as a potential source of genotypes and regenerants bearing structural changes in the chromosomes which 
obviously involve genetic changes of the corresponding degrees and, this in turn might result in the generation of somaclonal variants.

In tetraploid callus cell, ' $A$ ' group of chromosomes nonsatellited very long, meta-centric to nearly metacentric chromosomes appeared in considerable frequency $(A+A=25 \%$ ) (Table

Table 2. Frequency (\%) of normal (N) and structurally altered (SA) chromosomes in diploid, tetraploid and aneuploid callus cells of $H$. vulgare

\begin{tabular}{|c|c|c|c|c|c|c|c|}
\hline \multirow{3}{*}{$\begin{array}{c}\text { Chromosome } \\
\text { types }\end{array}$} & \multirow{3}{*}{$\begin{array}{c}\text { Control } \\
\text { karyo } \\
\text { type }\end{array}$} & \multicolumn{6}{|c|}{ Cultured cell karyotypes } \\
\hline & & \multicolumn{2}{|c|}{ Diploid cells } & \multicolumn{2}{|c|}{ Tetraploid cell } & \multicolumn{2}{|c|}{ Aneuploid cells } \\
\hline & & $\% \mathrm{~N}$ & $\% \mathrm{SA}$ & $\% \mathrm{~N}$ & $\% \mathrm{SA}$ & $\% \mathrm{~N}$ & $\% \mathrm{SA}$ \\
\hline$A_{1}$ & - & - & 10.0 & - & 17.9 & - & - \\
\hline $\mathrm{A}_{2}$ & - & - & 4.38 & - & 7.1 & - & 0.6 \\
\hline $\mathbf{B}_{1}$ & 42.9 & 31.4 & 1.4 & 28.6 & - & 20.0 & - \\
\hline $\mathbf{B}_{2}$ & - & - & 1.4 & - & 7.1 & - & 5.2 \\
\hline $\mathbf{B}_{4}$ & - & - & - & - & 7.1 & - & 7.7 \\
\hline $\mathrm{C}_{1}$ & 14.3 & 10.0 & - & - & - & 21.9 & - \\
\hline $\mathrm{C}_{2}$ & 14.3 & 5.7 & - & - & - & 8.4 & - \\
\hline $\mathrm{C}_{3}$ & - & - & 1.4 & - & 7.1 & - & 4.5 \\
\hline $\mathrm{C}_{4}$ & - & - & - & - & - & - & 1.9 \\
\hline $\mathbf{D}_{1}$ & - & - & 4.3 & - & 3.6 & - & 8.4 \\
\hline $\mathrm{D}_{2}$ & - & - & 1.4 & - & 3.5 & - & 5.2 \\
\hline $\mathbf{D}_{3}$ & - & - & 4.3 & - & - & - & 2.6 \\
\hline $\mathrm{D}_{4}$ & - & - & - & - & - & - & 2.6 \\
\hline $\mathrm{AS}_{1}$ & - & - & - & - & 7.1 & - & - \\
\hline $\mathrm{AS}_{2}$ & - & - & 1.4 & - & - & - & 0.6 \\
\hline $\mathrm{BS}_{1}$ & 28.5 & 7.1 & - & 3.6 & - & 3.9 & - \\
\hline $\mathbf{B S}_{2}$ & - & - & 1.4 & - & 7.1 & - & 1.9 \\
\hline $\mathrm{BS}_{3}$ & - & - & 1.4 & - & - & - & 0.6 \\
\hline $\mathrm{BS}_{4}$ & - & - & 1.4 & - & - & - & 0.6 \\
\hline $\mathrm{CS}_{1}$ & - & - & 2.9 & - & - & - & 1.3 \\
\hline $\mathrm{CS}_{2}$ & - & - & 4.3 & - & - & - & - \\
\hline $\mathrm{CS}_{3}$ & - & - & - & - & - & - & - \\
\hline $\mathrm{CS}_{4}$ & - & - & - & - & - & - & 0.6 \\
\hline $\mathrm{DS}_{1}$ & - & - & 2.9 & - & - & - & 1.3 \\
\hline $\begin{array}{c}\text { Total } \\
(\%)\end{array}$ & 100 & 54.2 & 44.2 & 32.2 & 67.7 & 54.2 & 45.6 \\
\hline
\end{tabular}

Table 3. Frequency $(\%)$ of different chromosome groups in cultured cell karyotypes of Hordeum vulgare L.

\begin{tabular}{lcccccccc}
\hline \hline \multirow{2}{*}{$\begin{array}{l}\text { Chromosome } \\
\text { groups }\end{array}$} & \multicolumn{8}{c}{ Frequency (\%) of different chromosomes groups } \\
\cline { 2 - 10 } & $\mathrm{A}$ & $\mathrm{B}$ & $\mathrm{C}$ & $\mathrm{D}$ & $\mathrm{AS}$ & $\mathrm{BS}$ & $\mathrm{CS}$ & $\mathrm{DS}$ \\
\hline a) $\begin{array}{l}\text { Cultured } \\
\text { cells }\end{array}$ & 7.1 & 34.8 & 28.1 & 15.0 & 1.6 & 8.7 & 3.2 & 1.6 \\
b) $\begin{array}{l}\text { Control } \\
\text { (root tips) }\end{array}$ & - & 42.9 & 28.6 & - & - & 28.6 & - & - \\
$\begin{array}{l}\text { Theoretical } \\
\text { difference* }\end{array}$ & 7.1 & -8.1 & -0.5 & 15.0 & 1.6 & -19.9 & 3.2 & 1.6 \\
\hline
\end{tabular}

* Theoretical difference $=b-a$

(Loss or grain of chromosomes of different groups by cultured cell karyotypes)

2). In tetraploid callus cells, the normal satellited chromosomes were reduced to $3.6 \%$, however, $7.4 \%$ satellited chromosomes were observed with minor structural alterations (Table 2). Total of $68 \%$ structurally alteread chromosomes were recorded from tegraploid callus cells. 
Thus compairing to diploid, the frequency of structurally altered chromosomes was higher in tetraploid callus cells. Similar trend was observed in callus cells of Crepis capillaries (Sacristan 1971). Hsu (1881) has also noted similar observation in animal cell cultures and reasoned it to be due to greater mitotic disturbances in polyploidized cells. Aneuploid cells of the culture also carried around $46 \%$ of structurally altered chromosomes in them (Table 2).

From the analysis of 14 cultured karyotypes, an estimate of gross deviation of chromosome structure from original groups are depicted in Table 3. In callus cell population, ' $\mathrm{C}$ ' group of chromosomes (medium sized (length 7-9.9 $\mu \mathrm{m}$ ) non satellited) observed to have maximum survival chances in culture condition, whereae, ' $\mathrm{B}$ ' group had lost $8 \%$ of the original group of chromosomes. Around $20 \%$ of the BS group (long, satellited chromosomes, length 10 $14.99 \mu \mathrm{m}$ ) chromosomes were eliminated from the cultured cells, compared to $28.6 \%$ present originally in control. However $4.8 \%$ were observed in structurally altered form. A new group "A" (very long, 15-24 $\mu \mathrm{m}$ length, non satellitead) chromosomes appeared in considerable frequency $(7 \%)$ in cultured cells. Other structurally altered chromosomes $(\mathrm{D}, \mathrm{AS}$, CS and DS group chromosomes) also observed at very low frequencies in cultured cells.

It is imperative from the present study that all the cultured metaphase cells carried structurally altered chromosomes in them and these aberrant cells have a positive selective value in in vitro culture systems. Even if latter is not proved, but similar assumption has been made from the study on the culture karyotypes of Crepis capillaries (Sacristan 1971). Such type of aberrant cell selection may be comparable to genetic drift. Regenerants from such cultures (Somaclonal variants) might be useful for the selection of useful genetic variants.

\section{Summary}

Structural aberrations of chromosomes of 150-day-old cultured cells of barley were examined by karyotypic analysis. Minor and major rearrangements were detected in chromosomes; all the metaphase cells analysed from the culture revealed the presence of aberrant chromosomes in them. Analysis of cultured diploid karyotypes showed the inclusion of $44 \%$ structurally aberrated chromosomes. It was observed that certain new karyotypes were originated due to chromosomal rearrangements, while the ploidy level remained same as that of original plant. Tetraploid cells carried greater frequency of aberrant chromosomes that diploid cells. Aneuploid cells of the culture also carried $48 \%$ structurally altered chromosomes in them. The significance of this study is discussed.

\section{References}

D'Amato, F. D. 1977. Cytogenetics of differentiation in tissue and cell cultures. in Applied and Fundamental Aspects of Plant Cell Tissue and Organ Culture (J. Reinert and Y. P. S. Bajaj Eds.) Springer-Verlag, pp. 343-357.

Evans, D. A. and Reed, S. M. 1981. Cytogenetic techniques in Plant Tissue Culture: Method and Application, in Agriculture (T. A. Thorpe Ed.) Academic Press, New York. pp. 214-236.

Hsu, T. C. 1981. Chromosome evolution in cell population. Intern. Rev. Cytol. 12: 69-161.

Karp, A. and Bright, S. W. J. 1985. On the causes and origins of somaclonal variation, in Oxford Surveys of Plant Molecular Biology (B. J. Miflin, Ed.). Oxford Univ. Press vol. 2. pp. 100-216.

Krikorian, A. D., O. Connor, S. A and Fitter, M. S. 1983. Chromosome number variation and karyotypic stability in cultures and culture dearived plants, in Hand Book of Plant Cell Culture. Vol. 1 (D. A. Evans, W. R. Sharp, P. V. Ammirato and Y. Yamada Eds.) McMillan pp. 541-573.

Larkin P. J. and Scowcroft, W. R. 1981. Somaclonal variation-a novel source of variability from cell cultures for plant improvement. Theor. Appl. Gent. 65: 197-214.

Mc Coy, T. J., Phillips, R. L. and Rines, H. W. 1982. Cytogenetic analysis of plant renegerated from Oat (Avena sativa) tissue culture: high frequency partial chromosome loss. Can. J. Genet. 24: 37-50. 
Mohanty, B. D. 1987. Cyto-morphogenetic studies in callus cultures of Hordeum vulgare L. Sorghum bicolor (L.) Moench. Ph. D thesis, University of Kalyani, India, pp. 35-44.

- 1990. Chromosomal analysis of cultured cells of barley (Hordeum vulgare L.): Chromosome number variation. Cytologia 55: $399-404$.

Muir, W. A. 1965. Influence of variation in chromosome number and differentiation, in Plant Tissue Cultures. in Proc. Intern. Congress of Plant Tissue Culture (P. R. White and A. R. Grove Eds.) pp. 485-492. Berkeley, Calif: Mc Cutchen.

Murashige, T. and Nakano, R. 1965. Morphogenetic behaviour of tobacco tissue cultures and implication of plant senescence. Amer. J. Bot. 52: 819-827.

Orton, T. J. 1980. Chromosomal variability in tissue cultures and regenerated plants of Hordeum Theor. Appl. Genet. 56: 101-112.

Pijnaker, L. P. and Ferweda, M. W. 1987. Karyotypic variation in amino ethylcysteine resistant cell and callus cultures and regenerated plants of a dihoploid potato (Solanum tuberosum). Plant Cell Rep. 6: $385-387$.

Sacristan, M. D. 1971. Karyotypic changes in callus cultures of haploid and diploid plants of Crepis capillaries (L.). Wallr. Chromosoma 33: 273-283.

Scowcroft, W. R. 1984. Somaclonal variation - A 'New' geneticre-source, in Genetics: New Frontiers (V. L. Chopra, R. P. Sharma and H. C. Ransal Eds.) Oxford IBH Publishing Co. pp. 35-48.

Sunderland, N. 1977. Nuclear cytology, in Plant Tissue and Cell Culture (H. E. Street Ed.) Blackwell Scientific Publishers Oxford pp. 177-205.

Torrey, J. G. 1967. Morphogenesis in relation to chromosomal constitution in long-term plant tissue cultures. Physiol. Plant 20: 265-275.

Vasil, I. K. 1983. Towards the development of a single cell system for grasses, Proc. of a workshop co-sponsored by the Institute of Genetics, Academia Sinica and International Rice Research Institute, Science Press and IRRI, Phillipines in: Cell and Tissue Cultures for Plant Improvement pp. 131-140. 